\title{
RESULT OF ENDOSCOPICALLY ASSISTED GASTROPEXY IN DOGS
}

\author{
ARICAN Mustafa ${ }^{1 *}$, PARLAK Kurtuluş ${ }^{1}$, INCE Mehmet Ege ${ }^{2}$, GÜZELBEKTEŞ \\ Hasan $^{2}$ \\ ${ }^{1}$ Department of Surgery, Faculty of Veterinary Medicine, The University of Selcuk, Konya/Turkey; \\ ${ }^{2}$ Department of Internal Medicine, Faculty of Veterinary Medicine, The University of Selcuk, Konya/ \\ Turkey
}

(Received 12 February; Accepted 11 April 2014)

The aim of this study was to investigate the use of endoscopy jointly with gastropexy in dogs as a potential mean to aid prevention and evaluation of the long-term efficiency of this procedure for gastric dilatation-volvulus.

The study was performed on ten healthy adult medium- and large-breed dogs. The dogs had no abnormal finding upon physical examination and each underwent an endoscopically assisted gastropexy procedure. After surgery all dogs were in good condition. The surgical procedure was followed by $\mathrm{x}$-ray and ultrasonographic examinations. The records included data for gastropexy anatomic location and length, duration of the surgical procedure and complications.

The mean \pm SD gastropexy length was $3.0 \pm 0.25 \mathrm{~cm}$, as determined by ultrasonography, and the mean duration of the surgical procedure was $20 \pm 5$ minutes.

It appears that endoscopically assisted gastropexy is a simple, fast, safe, and reliable method of performing a prophylactic gastropexy in dogs. This procedure maximizes the benefits of decreased morbidity and shorter duration of anaesthesia associated with minimally invasive surgery.

Key words: dog, endoscopical gastropexy, X-ray, ultrasound

\section{INTRODUCTION}

Gastric dilatation volvulus (GDV) syndrome is an acute condition with a mortality rate of $20 \%$ to $45 \%$ in treated animals. The gastric enlargement is thought to be associated with a functional or mechanical gastric outflow obstruction. The initiating cause of the outflow obstruction is unknown; however, once the stomach dilates, normal physiologic means of removing air (i.e., eructation, vomiting, and pyloric emptying) are hindered because the oesophageal and pyloric portals are obstructed [1-3].

Early recognition of the condition combined with rapid gastric decompression, appropriate treatment for hypovolemic shock and reperfusion injury, and management

* Corresponding author: e-mail: marican@selcuk.edu.tr 
of cardiac dysrhythmias decreases the risk of death associated with the disease [4]. If untreated, intragastric pressure will increase and, in turn, often result in cardiogenic shock and eventual death. Medical treatment alone is inadequate and as many as $81 \%$ of affected dogs die within a year of initial treatment if surgery is not performed $[5,6]$. Gastropexy techniques are designed to permanently fix the stomach to the body wall. Numerous gastropexy techniques have been described. Although the strength and extent of adhesions created by these techniques differ, all of them prevent movement of the stomach. Failure to perform a gastropexy at the time of surgery results in a recurrence rate $>50 \%$; when a gastropexy is performed, the recurrence rate is $6 \%$ to $10 \%$ [7]. Given the unacceptably high risk of recurrence without gastropexy, it is considered the "standard of care" to perform the procedure at the time of surgical treatment of GDV [6]. The lifetime risk of certain predisposed dogs to develop GDV has been estimated to be $4 \%$ to $37 \%$ [6]. Because GDV is such a serious disease and a certain subset of dogs is predisposed to the disease, the recommendation of many veterinarians is that gastropexy should be performed prophylactically in predisposed breeds [4,7-11].

Techniques commonly used to perform a gastropexy during emergency surgery for GDV can also be used for prophylactic gastropexy [12]. Almost all gastropexy techniques developed for use during a laparotomy can also be performed through laparoscopic or laparoscopic-assisted surgery [12-15]. The advantages of these gastropexy techniques are that they are easy to perform, produce a permanent attachment between the antrum and the right abdominal wall, do not alter gastric function, and have minimal complications. These include a grid gastropexy and a laparoscopically assisted gastropexy. However, both of these procedures are relatively time consuming and the laparoscopically assisted gastropexy requires a considerable amount of instrumentation [16-18]. By using endoscopically assisted gastropexy, clinicians can potentially perform an otherwise invasive procedure in a shorter period of time. The development of such a procedure would establish a quick, inexpensive, repeatable, and minimally invasive method of performing a prophylactic gastropexy. This technique would also have the advantage of requiring less equipment in contrast to that required for currently used gastropexy procedures.

Ultrasonographic anatomy provides important landmarks for differentiating anatomic variants from pathologic changes. Normal sonographic gastrointestinal anatomy has been described extensively in animals [19]. In dogs, the stomach is easily recognised by the presence of rugae and regular peristaltic activity [20]. On the other hand, survey radiographs may be sufficient to diagnose some gastric abnormalities and thus preclude the need for contrast studies [21,22].

The purpose of the study reported here was to evaluate the use of endoscopic-assisted prophylactic gastropexy and determine the duration of surgery, complications, and long-term outcome including prevention of gastric dilatation-volvulus (GDV) by ultrasonography and radiography. 


\section{MATERIAL AND METHODS}

\section{Dogs}

Ten healthy mixed medium and large breed dogs that weighed 15 to $35 \mathrm{~kg}$ were used for the study. Hematologic analysis was assessed prior to inclusion in the study; findings were within reference limits. The study was performed with the approval from and under the guidelines of the Institutional Laboratory Animal Care and use Committee of Selcuk University. The dogs were followed up for six months.

\section{Surgical technique}

Food was withhold from each dog for 12 hours before anaesthesia. The dogs were intravenously preanesthetized with xylacine hydrochloride (Alfazyne $2 \% 20 \mathrm{mg} / 1 \mathrm{ml}$ ) and ketamine hydrochloride (Alfamine $10 \%, 100 \mathrm{mg} / 1 \mathrm{ml}$ ). After 10 minutes, anesthesia was maintained with isoflurane in oxygen (AErrane, Baxter 2-4\%).

The hair on the abdomen was clipped, and the area was scrubbed in preparation for surgery. Lactated Ringer's solution was administered IV at a rate of $10 \mathrm{~mL} / \mathrm{kg} / \mathrm{h}$. The dog was positioned in a left oblique recumbence at approximately 30 degrees to the plane perpendicular to the operating table. Endoscope $(105 \mathrm{~cm}, 9.8$ diameters, Olympus visera OTV-S7 Japan) was used. The scope was passed orally down to the stomach, and the stomach was then insufflated with air until rugal folds were minimally visible and adequate distension was achieved. Occasionally, the cervical portion of the oesophagus was compressed by an assistant to help achieve gastric distension. External palpation across the body wall was then performed with a curved hemostat forceps while the pyloric antrum was viewed to identify the chosen anatomic site. The stomach was briefly evaluated for any masses or lesions. Once orientation was achieved, size0 or size- 2 polypropylene suture on a cutting needle (needle length, 80 and $90 \mathrm{~mm}$, respectively) was passed through the right lateral aspect of the body wall (immediately caudal to the 13th rib) (Fig. 1); the needle and suture were viewed endoscopically as they entered and exited the stomach at the level of the pyloric antrum and then exited the body wall again through the skin (Fig. 2 and Fig. 3). The suture was then pulled tight and temporarily secured in place with mosquito haemostats. An additional length of suture was then passed approximately 4 to $5 \mathrm{~cm}$ from the initial suture in the region of the pyloric antrum aborad to the first suture position. An incision was performed through the layers of the abdominal musculature between the 2 stay sutures until the stomach was visible (Fig. 4). The incision differed in orientation but was commonly parallel to the 13th rib. Two Gelpi retractors were placed perpendicular to each other in the incision to assist viewing. A longitudinal incision (approx 3- to 4-cm long) was then made through the serosal and muscular layers of the pyloric antrum. The seromuscular layer was sutured to the transversus abdominis muscle in 2 individual continuous patterns with size- 0 polypropylene suture. The obliquus externus abdominis muscles were then approximated with 2-0 polydioxanone suture 
in a simple interrupted pattern [4]. The subcutaneous tissues and skin were closed in routine fashion. The stay sutures previously placed were removed while the stomach was endoscopically evaluated and decompressed.

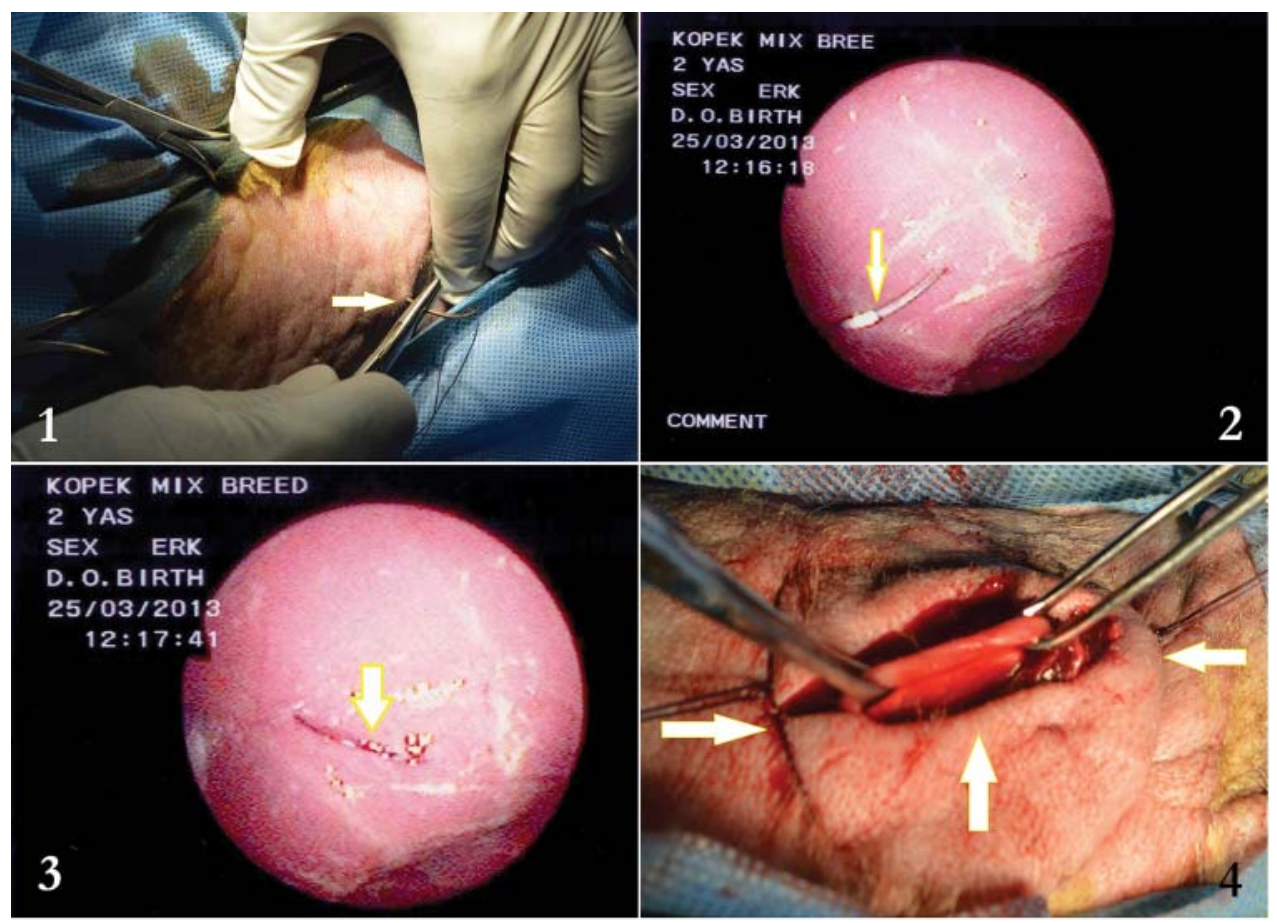

Figure 1. Once orientation was achieved, size- 0 or size- 2 polypropylene suture on a cutting needle was passed through the right lateral aspect of the body wall (immediately caudal to the 13th rib). The arrow indicates the cutting needle. Figure 2. The needle was viewed endoscopically as it entered and exited the stomach at the level of the pyloric antrum. The arrow indicates the endoscopical view of the needle. Figure 3. The suture was viewed endoscopically as it entered and exited the body wall through the skin. The arrow indicates the endoscopical view of the needle. Figure 4. The suture was pulled tight and temporarily secured in place. An additional length of suture was then passed approximately 4 to $5 \mathrm{~cm}$ from the initial suture in the region of the pyloric antrum aborad to the first suture position. An incision was performed through the layers of the abdominal musculature between the 2 stay sutures until the stomach was visible. See arrows.

\section{Biochemical analysis}

Blood samples $(5 \mathrm{ml})$ were taken before gastropexy and postoperative after 7 days. White blood cell (WBC), red blood cell (RBC), hemoglobulin $(\mathrm{Hg})$, hematocrit $(\mathrm{Ht})$, $\mathrm{pH}$, partial venous oxygen blood pressure $\left(\mathrm{PO}_{2}\right)$, partial venous carbondioxide pressure $\left(\mathrm{PCO}_{2}\right)$, total carbondioxide $\left(\mathrm{tCO}_{2}\right)$, bicarbonate $\left(\mathrm{HCO}_{3}\right)$, sodium $(\mathrm{Na})$, potassium (K), calcium (Ca) and glucose (Glu) were measured by Gem Premier 3000 (Biomerieux Diagnostic A.S.) and Hemocelle counter (Medonic CA 530 Thor, Sweden). 


\section{Radiological Examinations}

Postoperative, on the 7th day, direct and contrast medium radiological examinations, ventrodorsal, left recumbent lateral view, right recumbent lateral view and dorsoventral view imaging was done by using Sp-HF-4.0 Ralco marka Spain; Imago, Abbiategrasso, Milano; Regius Model 110 Konica, Minolta.

\section{Ultrasonographic Examinations}

Preparation included clipping and shaving, followed by antiseptic washing and rinsing with alcohol. Acoustic gel was applied to the ventral abdominal wall. Dorsal and right lateral recumbence were the positions for examination. The stomach was scanned from the fundus to the pylorus in both transverse and sagittal planes. A diagnostic ultrasound machine (Esaote Piemedikal, Model 410477) with a $5-7.5 \mathrm{MHz}$ convex transducer was used. Images were printed using a video printer and thermal sensitive paper. Stomach and pyloric wall thickness was measured, and gastric peristalsis was recorded.

\section{Statistical analysis}

Mean, median, range, and $\mathrm{SD}$ values of duration of the surgical procedure, gastropexy length, and body weight were calculated.

\section{RESULTS}

The mean \pm SD duration of surgery was $20 \pm 5$ minutes. Mean gastropexy length was $3.0 \pm 0.25 \mathrm{~cm}$. The time for introduction of the gastroscope into the stomach and achievement of adequate insufflations was approximately 1 minute.

\section{Biochemical analysis}

There were no statistical differences for preoperative and 7 days post operative for (WBC), (RBC), ( $\mathrm{Hg}),(\mathrm{Ht}), \mathrm{pH},\left(\mathrm{PO}_{2}\right),\left(\mathrm{PCO}_{2}\right),\left(\mathrm{tCO}_{2}\right),\left(\mathrm{HCO}_{3}\right),(\mathrm{Na}),(\mathrm{K}),(\mathrm{Ca})$ and (Glu) levels. They were all within references values.

\section{Radiological Examinations}

There were no abnormalities on direct radiographic examination 7 days postoperative. On the left recumbent lateral view, the pyloric portion was well visualised. Gastric emptying started within 15 minutes and stomach was empty within 4 hours. There was no pyloric obstruction.

\section{Ultrasonographic Examinations}

Postoperative 7 days, the stomach showed on ultrasound a layered appearance. The mucosa and muscularis were corresponding by hypoechoic layers. The remaining layers were hyperechoic. Pyloric layers displayed a wide hyperechoic area. Measurements of 
the stomach wall thickness were about $4 \mathrm{~mm}$, and pyloric layers were $6 \mathrm{~mm}$ thick. Gastric peristalsis numbered 6 contractions per minute. Pylorospasm was not seen.

\section{Surgical Results}

After insertion of the needle into the pyloric antrum, a minimal amount of haemorrhage was detected endoscopically. Minor haemorrhage was associated with the body wall incision during gastropexy. On physical inspection, all gastropexies were positioned at the level of the pyloric antrum. There was no evidence of improper surgical technique, damage to other organs, or entrapment of viscera.

The dogs were followed-up for 6 months and there were no complications.

\section{DISCUSSION}

The goals of surgical treatment are to inspect the stomach and spleen in order to identify and remove damaged or necrotic tissue, to decompress the stomach and correct any malpositioning, as well as to fix the stomach to the body wall to prevent subsequent malpositioning [2]. In the short-term period following GDV surgery, mortality rates among dogs can reach approximately $15 \%$ to $33 \%[1,23,24]$. Ward et al (2003) [10] reported that the lifetime risk of development of GDV ranges from 4\% to $37 \%$ in predisposed breeds of dog. In contrast, the lifetime risk of development of GDV if a prophylactic gastropexy is performed is $0.3 \%$. Depending on the breed of dog, prophylactic gastropexy results in a 2 - to 30 -fold reduction in lifetime mortality rate [10]. Additionally, there is a $92 \%$ reduction in risk for development of GDV when a prophylactic gastropexy is performed [24]. On the basis of those findings, prophylactic gastropexy can be suggested for dogs of predisposed breeds because it decreases GDV-associated mortality rates [4]. However, there are several considerations that must be taken into account before performing a prophylactic gastropexy in a dog. Laparoscopic techniques are used more frequently than endoscopic techniques in veterinary medicine. An endoscopically assisted gastropexy successfully minimizes the number and size of surgical incisions. This theoretically should result in a decreased duration of anaesthesia, degree of postoperative pain and requirements for analgesia, incidence of incision complications, duration of hospitalization, and cost $[3,25,26]$. Additionally, this minimally invasive technique allows for a decrease in the amount of equipment necessary to perform the procedure, compared with that required for other currently used minimally invasive laparoscopically assisted gastropexy procedures $[8,9,16,18]$. Endoscopically assisted gastropexy is more commonly available in private practice compared with laparoscopic equipment. It was also agreed by Dujowich and Reimer, [4]. This procedure will result in greater owner acceptance of prophylactic gastropexies as a mean for preventing GDV among predisposed breeds. GDV is prevented most successfully by maintaining the stomach in its normal anatomic location via a prophylactic gastropexy supported with ultrasonographic and radiographic examinations. It has contributed to the development of less invasive prophylactic 
gastropexy procedures $[8,9,16,18]$. The ideal gastropexy technique is simple to perform, permanently and predictably attaches the stomach to the abdominal wall in a correct anatomic position to prevent volvulus, does not interfere with gastric function, is associated with minimal intraoperative and postoperative complications, and requires minimal postoperative management of the treated dog [11]. There are many gastropexy techniques, including incision gastropexy, tube gastrostomy, circumcostal gastropexy, belt-loop gastropexy and laparoscopically assisted gastropexy. All these techniques have been assessed, and each has been found to be an acceptable method of performing gastropexy [23,27-33]. Any of these techniques can be performed prophylactically; however, all but the laparoscopically assisted gastropexy and the grid approach require a laparotomy $[8,9,16,18]$. Given the similarities in the actual surgical procedure itself (suturing the seromuscular layer of the stomach to the transversus abdominus muscle), it is appropriate for one to assume that immediate tensile and long-term adhesion strengths of the endoscopically assisted gastropexy should be similar to those previously reported [16,18] for gastropexies performed in the same anatomic region. Compared with other techniques, the endoscopically assisted procedure may help avoid accidental duodenopexy and decrease the number of incisions necessary to perform the procedure and duration of surgery [4]. The endoscopically assisted gastropexy in the present study was performed quickly and without any complications. The results indicated that duration of surgery was typically $<25$ minutes. Similar results were also shown by Dujowich and Reimer, [4]. In this study we have not seen any complications such as needle breakage and occlusion of the cervical portion of the oesophagus during observation of the pyloric antrum. However, endoscopic equipment and experience are a necessity. Use of an endoscope simplifies the procedure and adheres to the principles of minimally invasive surgery. There are several important factors as we see our study to ensure a simple and successful gastropexy by the use of this endoscopically assisted technique; these include adequate withholding of food from the dog prior to surgery and proper patient positioning, needle selection and insufflations as described by Dujowich and Reimer [4]. After gastropexy, withholding of food for an adequate period is necessary to view the pyloric antrum. Without proper positioning, there is a possibility of accidental damage to another organ or entrapment of a loop of intestine during placement of the stay sutures in the stomach wall. Furthermore, a large and strong cutting needle is critical to avoid bending and breaking of the needle. We have used a $80 \mathrm{~mm}$ needle and did not record any complications. In the present study, a rapid, inexpensive, and reliable method for performing an endoscopically assisted gastropexy in dogs was developed and assessed. The endoscopically assisted gastropexy potentially maximizes the benefits associated with minimally invasive surgery, including reduced incision size, decreased postoperative pain and analgesic drug requirements, and more rapid restoration of normal intestinal tract function [27,34]. This study considered the evaluation of the long-term efficiancy of endoscopically assisted gastropexy in dogs predisposed to GDV, as determined by ultrasonograhic and radiographic examination. 


\section{REFERENCES}

1. Brockman DJ, Washabau, RJ, Drobatz KJ: Canine gastric dilatation/ volvulus syndrome in a veterinary critical care unit: 295 cases (1986-1992). JAVMA, 2003, 207:460-464.

2. Fossum T: Small Animal Surgery, Elsevier, London, 2013.

3. Krstic V, Marinkovic D, Vakanjac Slobodanka, Lalosevic D, Aleksic-Kovacevic S: Helicobacter Spp. in gastroscopic biopsies in dogs. Acta Vet-Beograd, 2006, 56; 305-314.

4. Dujowich M, Reimer, SB: Evaluation of an endoscopically assisted gastropexy technique in dogs. AJVR, 2008, 69: 537-541

5. Eggertsdottir AV, Moe L: A retrospective study of conservative treatment of gastric dilatation-volvulus in the dog. Acta Vet Scand, 1995, 36: 175-184.

6. Ellison GW: Gastric dilatation volvulus: surgical prevention. Vet Clin N Am-Small, 1993, 23: 513-530.

7. Glickman LT, Glickman NW, Schellenberg DB, Raghavan M, Lee T: Non-dietary risk factors for gastric dilatation-volvulus in large and giant breed dogs. JAVMA, 2000, 217: 1492-1499.

8. Rawlings CA, Mahaffey MB, Bement S, Canalis C, 2002, Prospective evaluation of laparoscopic-assisted gastropexy in dogs susceptible to gastric dilatation. JAVMA, 2002, 221: 1576-1581.

9. Rawlings CA: Laparoscopic-assisted gastropexy. J Am Anim Hosp Assoc, 2002, 38: $15-19$.

10. Ward MP, Patronek, GJ, Glickman LT: Benefits of prophylactic gastropexy for dogs at risk of gastric dilatation volvulus. Prev Vet Med, 2003, 60: 319-329.

11. Whitney WO: Complications associated with the medical and surgical management of gastric dilatation-volvulus in the dog. Probl Vet Med, 1989, 1: 268-80.

12. Rivier P, Furneaux R, Viguier E: Combined laparoscopic ovariectomy and laparoscopicassisted gastropexy in dogs susceptible to gastric dilatation-volvulus. Canadian Vet J, 2011, 52: 62-66.

13. Schauer P, Chand B, Brethauer S: New applications for endoscopy: the emerging field of endoluminal and transgastric bariatric surgery. Surg Endosc, 2007, 21: 347-356.

14. Vitale GC, Davis BR, Tran TC: The advancing art and science of endoscopy. Am J Surg, 2005, 190: 228-233.

15. Genter A, Capak H, Lipar M, Samardžıja M, Harapın I, Bedrica L, Capak D: Antimicrobial prophylaxis in addition to premedication in gastrointestinal surgery. Acta Vet-Beograd, 2014, 64: 149-155.

16. Rawlings CA, Foutz TL, Mahaffey MB, Howerth EW, Bement S, Canalis C: A rapid and strong laparoscopic-assisted gastropexy in dogs. AJVR, 2001, 62: 871-875.

17. Steelman-Szymeczek SM, Stebbins ME, Hardie EM: Clinical evaluation of a right-sided prophylactic gastropexy via a grid approach. J Am Anim Hosp Assoc, 2003, 39: 397-402.

18. Wilson ER, Henderson RA, Montgomery RD, Kincaid SA, Wright JC, Hanson RR: A comparison of laparoscopic and belt-loop gastropexy in dogs. Vet Surg, 1996, 25: 221-227.

19. Nyland TG, Mattoon JS: Veterinary Diagnostic Ultrasound. W.B. Saunders, London, 1995.

20. Barr F, Gaschen L: BSAVA Manual of Canine and Feline Ultrasonography. Replika Press Pvt. Ltd. India, 2011. 
21. Arican M: Atlas of Veterinary General Radiology \& Diagnostic Radiography in Cat and Dogs. Bahçıvanlar, Konya, 2011.

22. Thrall DE: Textbook of Veterinary Diagnostic Radiology. W.B. Saunders, London, 1986.

23. Brourman JD, Schertel ER, Allen DA, Birchard SJ, Dehoff WD: Factors associated with perioperative mortality in dogs with surgically managed gastric dilatation-volvulus: 137 cases (1988-1993). JAVMA, 1996, 208: 1855-1858.

24. Glickman LT, Lantz GC, Schellenberg DB, Raghavan M, Lee T: A prospective study of survival and recurrence following the acute gastric dilatation- volvulus syndrome in 136 dogs. J Am Anim Hosp Assoc, 1998, 34: 253-259.

25. Prokic B, Todorovic V, Drndarevic N, Vignjevic S, Dikic D, Nikolic I, Marinkovic S, Slavik E: Idiopathic and secondary acquired megacolon in dogs is associated with diminished vasoactive intestinal polypeptide innervation of the affected colon. Acta Vet-Beograd, 2009, 59: 53-68.

26. Dordevic M, Krstic V, Krstic N, Vas1ljevic M, Ilic V, Vucıcevic I, Aleksic-Kovacevic S: Morphological, immunophenotypic and clinical characteristics of dogs with lymphocytic plasmacytic duodenitis. Acta Vet-Beograd, 2012, 62: 445-454.

27. Beger HG, Schwarz A, Bergmann U: Progress in gastrointestinal tract surgery: the impact of gastrointestinal endoscopy. Surgical Endoscopy 2003, 17: 342-350.

28. Fox SM, Ellison GW, Miller GJ, Howells D: Observations on the mechanical failure of three gastropexy techniques. J Am Anim Hosp Assoc, 1985, 21: 729-734.

29. Johnson RG, Barrus J, Greene RW: Gastric dilatation-volvulus: recurrence rate following tube gastrostomy. J Am Anim Hosp Assoc, 1984, 20: 33-37.

30. Leib MS, Konde LJ, Wingfield WE, Twedt DC: Circumcostal gastropexy for preventing recurrence of gastric dilatation-volvulus in the dog: an evaluation of 30 cases. J Am Anim Hosp Assoc, 1985, 187: 245-248.

31. MacCoy DM, Sykes GP, Hoeffer RE, Harvey HJ: A gastropexy technique for permanent fixation of the pyloric antrum. J Am Anim Hosp Assoc, 1982, 18: 763-768.

32. Meyer-Lindenberg A, Harder A, Feher M, Luerssen D, Brunnberg L: Treatment of gastric dilatation-volvulus and a rapid method for prevention of relapse in dogs: 134 cases (19881991). JAVMA, 1993, 203: 1303-1307.

33. Woolfson JM, Kostolich M: Circumcostal gastropexy: clinical use of the technique in 34 dogs with gastric dilatation-volvulus. J Am Anim Hosp Assoc, 1986, 22: 825-30.

34. Robinson TN: Stiegmann, GV: Minimally invasive surgery. Endoscopy 2004, 36: 48-51.

\title{
REZULTATI ENDOSKOPSKI ASISTIRANE GASTROPEKSIJE KOD PASA
}

\author{
ARICAN Mustafa, PARLAK Kurtuluş, INCE Mehmet Ege, GÜZELBEKTEŞ Hasan
}

Cilj studije je bio da se ispita istovremena upotreba endoskopije sa gastropeksijom kod pasa, kao potencijalno podesna metoda za prevenciju i evaluaciju gastričke dilatacijevolvulusa, kao i efikasnost duže primene ove tehnike. Ispitivanje je obavljeno na 10 
zdravih, odraslih pasa, srednjih i velikih rasa. Svaki pas je podvrgnut endoskopiji zajedno sa procedurom gastropeksije. Obavljeni su radiografski pregledi kao i pregledi ultrazvukom i sve životinje su bile dobrog zdravstvenog stanja. Podaci koji su dobijeni, odnosili su se na anatomsku lokaciju gastropeksije, dužinu trajanja hirurške procedure kao i moguće komplikacije. Srednja vrednost $( \pm S D)$ dužine gastropeksije, dobijena ultrazvučnim pregledom je bila $3,0 \pm 0,25 \mathrm{~cm}$, a srednja vrednost dužine trajanja hirurške procedure je bila $20 \pm 5$ minuta. Na osnovu rezultata, može se pretpostaviti da je endoskopski asistirana gastropeksija jednostavna, brza, bezbedna i pouzdana metoda prilikom profilaktičke gastropeksije kod pasa. Ovom metodom smanjuje se morbiditet, kratko traje anestezija, uz maksimalnu redukciju invazivne hirurške metode. 